\title{
THE
}

1985

\section{Gulf Stream and wind-induced current variability on the Georgia continental shelf, winter 1978}

$\mathrm{Li} \mathrm{Li}$

University of Rhode Island

Mark Wimbush

University of Rhode Island, mwimbush@uri.edu

D. Randolph Watts

University of Rhode Island, randywatts@uri.edu

Alex J. Brincko

University of Rhode Island

Thomas N. Lee

Follow this and additional works at: https://digitalcommons.uri.edu/gsofacpubs

Terms of Use

All rights reserved under copyright.

\section{Citation/Publisher Attribution}

Li, L., Wimbush, M., Watts, D. R., Brincko, A. J., and Lee, T. N. ( 1985), Gulf Stream and wind-induced current variability on the Georgia continental shelf, winter 1978, J. Geophys. Res., 90( C2), 3199- 3210, doi: 10.1029/JC090iC02p03199.

Available at: https://doi.org/10.1029/JC090iC02p03199

This Article is brought to you for free and open access by the Graduate School of Oceanography at DigitalCommons@URI. It has been accepted for inclusion in Graduate School of Oceanography Faculty Publications by an authorized administrator of DigitalCommons@URI. For more information, please contact digitalcommons-group@uri.edu. 


\title{
Gulf Stream and Wind-Induced Current Variability On the Georgia Continental Shelf, Winter 1978
}

\author{
Li Li, ${ }^{1}$ Mark Wimbush, D. Randolph Watts, and Alex J. Brincko \\ Graduate School of Oceanography, University of Rhode Island, Kingston
}

Thomas N. LeE

\begin{abstract}
School of Marine and Atmospheric Science, Division of Meteorology and Physical Oceanography
\end{abstract} University of Miami, Florida

\begin{abstract}
Low-frequency longshore current fluctuations on the continental shelf off Georgia and their relationships with local atmospheric forcing and Gulf Stream displacement were examined for a 3-month period from January to April 1978. (Acoustic travel tıme and bottom pressure measurements at a station on the continental slope were used to determine the depth of the main thermocline, as an indicator of Gulf Stream displacement.) On the middle shelf, current variability was dominated by local wind forcing at periods longer than 2 days, with very little Gulf Stream influence. Longshore wind stress was the main driving force at periods longer than 4 days, while cross-shore wind contributed at shorter periods. In contrast, on the outer shelf, current fluctuations in the upper layer were highly coherent with Gulf Stream displacement at a 12-day period, and marginally coherent with longshore wind at a 6-day period. Linear regression analysis showed that Gulf Stream and local wind forcing accounted for most of the fluctuations in the upper layer over the shelf break for time scales greater than 5 days and at around 2 days. A low multiple coherence window at $2.8-5$ days was probably due to Gulf Stream frontal eddies. In the lower layer over the shelf break the current fluctuations had a character intermediate between the upper layer currents (Gulf Stream dominated) and mid-shelf currents (wind dominated).
\end{abstract}

\section{INTRODUCTION}

The southeast United States continental shelf from Cape Canaveral to Cape Hatteras, usually called the South Atlantic Bight (SAB), has been studied intensively during the past decade (see the review by Blanton in Allen et al. [1983]). The $\mathrm{SAB}$ has a relatively broad continental shelf ranging from 30 $\mathrm{km}$ off Cape Hatteras to $120 \mathrm{~km}$ off Georgia and is bounded by the Gulf Stream to the east. Both atmospheric and Gulf Stream forcing strongly affect the shelf circulation. River runoff is also important in the southern SAB, but its effect is usually restricted to the inner shelf.

The broad, gently sloping continental shelf off Savannah, Georgia, located at the middle of the SAB, terminates at a 75 -m-deep shelf break $120 \mathrm{~km}$ from shore. From there a steep slope extends down to $400 \mathrm{~m}$, and beyond this lies the moderately sloping Blake Plateau which reaches 1000-m depth at $350-\mathrm{km}$ from shore. The Gulf Stream flows northeastward along the continental slope, and just downstream of the Savannah section it is deflected seaward by a protruding feature on the slope called the Charleston Bump [Brooks and Bane, 1978; Pietrafesa et al., 1978; Legeckis, 1979]. From January through early April, mean shelf wind off Georgia is nearly offshore [Weber and Blanton, 1980; Saunders, 1977; Weisberg and Pietrafesa, 1983], and the mean currents on the Georgia shelf are small compared with those to the south [Lee and Atkinson, 1983]. There is evidence that low-frequency currents on the inner and outer shelf are governed by different dynam-

\footnotetext{
1 Permanent address: Third Inslitute of Oceanography, National Bureau of Oceanography, Xiamen, People's Republic of China.

Copyright 1985 by the American Geophysical Union.

Paper number 4C1274.

$0148-0227 / 85 / 004 C-1274 \$ 05.00$
}

ics. Lee and Brooks [1979] report that current and temperature fluctuations at the shell break result primarily from Gulf Stream events, and that low-frequency current variability at the $50-\mathrm{m}$ isobath transition region between middle and outer shelf is a mixed response to local wind and Gulf Stream eflects. At the 30-m isobath (middle shelf), low-frequency current variability is primarily a local wind response [Lee et al., 1984]. Shell currents and upwellings associated with Gulf Stream frontal eddies over the middle and outer shelf off Georgia have been studied by Lee et al. [1981], Lee and Atkinson [1983], McClain et al. [1984], and Lee et al. [1984], but more observations are needed to establish the details.

Lateral migration of the Gulf Stream also affects the shelf currents. Brooks and Bane [1981] and Bane et al. [1981] have observed at Onslow Bay, North Carolina, that northeastward current velocity maxima occur as shoreward meander crests pass by. The relationship between local wind forcing and lowfrequency current fluctuations on the shelf off Georgia has been studied by Lee and Brooks [1979], Lee et al. [1981], Lee and Atkinson [1983] and Tebeau and Lee [1979]. The longshore current at the middle shelf is basically barotropic and wind driven [Lee et al., 1982]. Longshore current fluctuations are coherent with longshore wind, but for different observation times the coherence peaks occur at different frequencies. Longshore currents at the shelf break are incoherent or only marginally coherent with longshore wind. Apparently Gulf Stream influence is much stronger there. The wind forcing can be related to wind velocity measured on shore, but the measurement of forcing from the meandering Gulf Stream is a problem. Standard methods of observation of the Gulf Stream are costly or inadequate as means of generating time series of its position. Ship-borne hydrographic surveys are very expensive, and satellite imagery is both restricted to the sea surface and limited to regions of cloud-free skies.

In order to solve this problem, inverted echo sounders (IES's) were deployed to measure the main thermocline depth 


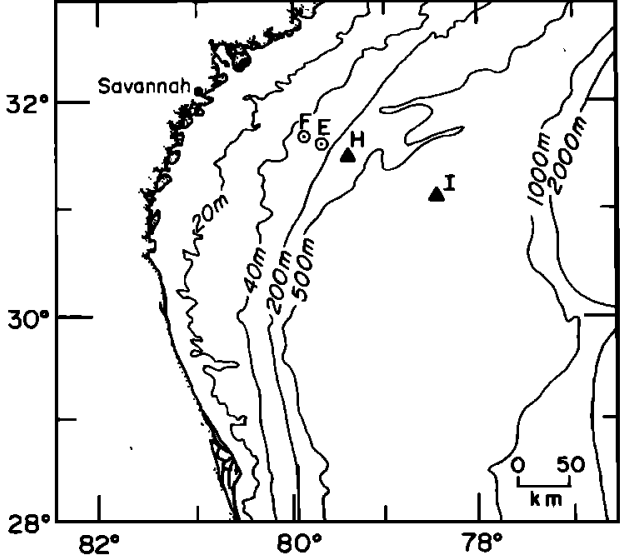

Fig. 1. Locations of current meter moorings $E$ and $F$ (circled dots), inverted echo sounder moorings $\mathbf{H}$ and $\mathbf{I}$ (triangles), atmospheric pressure and wind station (solid circle).

and hence infer Gulf Stream lateral displacement. This paper presents the results from the IES's and discusses the lowfrequency current variability of the middle and outer continental shelf off Savannah, Georgia, during winter 1978, in relation to the wind and Gulf Stream forcing.

\section{Observation Methods}

\subsection{Data}

Aanderaa current meters, pressure temperature recorders [Wimbush, 1977], and IES's [Bitterman and Watts, 1979] were deployed across the shelf and upper slope off Savannah Georgia, for a 3-month period from late January to mid April 1978 (Figure 1, Table 1). Current and temperature were recorded 17 $\mathrm{m}$ below the surface and $3 \mathrm{~m}$ above the bottom at stations $F$ and $E$ located at the $45-\mathrm{m}$ and $75-\mathrm{m}$ isobaths. Bottom pressure and temperature were also recorded at stations $\mathbf{F}$ and $\mathbf{E}$. IES's, equipped to record bottom pressure and temperature in addition to acoustic travel time, were installed at stations $\mathbf{H}$ and I located at the 265 - and $589-\mathrm{m}$ isobaths to trace the lateral meandering of the Gulf Stream. Six-hourly wind and atmospheric pressure data were obtained from the National Weather Service meteorological station at Savannah airport, approximately $20 \mathrm{~km}$ inland from the coast.

The current data were 3-hour low-pass filtered and subsampled as hourly time series. The wind data were linearly interpolated to a one hour interval. Current and wind components were converted to a local "topographic" coordinate system,

TABLE 1. Mooring Summary

\begin{tabular}{|c|c|c|c|c|c|}
\hline Mooring & Coordinates & $\begin{array}{l}\text { Water } \\
\text { Depth, } \\
\text { m }\end{array}$ & $\begin{array}{l}\text { Instrument } \\
\text { Designation }\end{array}$ & $\begin{array}{l}\text { Instrument } \\
\text { Depth, } \\
\text { m }\end{array}$ & $\begin{array}{c}\text { Data } \\
\text { Type* }\end{array}$ \\
\hline \multirow[t]{2}{*}{$F$} & $31^{\circ} 39.6^{\prime} \mathrm{N}$ & 45 & FTOP & 17 & $u, v, T$ \\
\hline & $79^{\circ} 50.9^{\prime} \mathrm{W}$ & & FBOT & 42 & $u, v, T$ \\
\hline $\mathrm{E}$ & $\begin{array}{l}31^{\circ} 35.8^{\prime} \mathrm{N} \\
79^{\circ} 40.2^{\prime} \mathrm{W}\end{array}$ & 75 & $\begin{array}{l}\text { ETOP } \\
\text { EBOT }\end{array}$ & $\begin{array}{l}17 \\
72\end{array}$ & $\begin{array}{l}u, v, T \\
u, v, T\end{array}$ \\
\hline $\mathbf{H}$ & $\begin{array}{l}31^{\circ} 33.5^{\prime} \mathrm{N} \\
79^{\circ} 29.4^{\prime} \mathrm{W}\end{array}$ & 265 & & 264 & $\tau, P, T$ \\
\hline I & $\begin{array}{l}31^{\circ} 15.1^{\prime} \mathrm{N} \\
78^{\circ} 32.2^{\prime} \mathrm{N}\end{array}$ & 589 & & 588 & $\tau, \boldsymbol{P}, T$ \\
\hline
\end{tabular}

*Parameters are $u, v$, current components; $\tau$, acoustic travel time; $P$, bottom pressure; and $T$, temperature.
TABLE 2. Computed Coefficients of Equation (2)

\begin{tabular}{ccccc}
\hline Station & $\begin{array}{c}A, \\
\mathrm{~s} / \mathrm{m}\end{array}$ & $\begin{array}{c}B, \\
\mathrm{~s} / \mathrm{m}\end{array}$ & $\begin{array}{c}C, \\
\mathrm{dbar} / \mathrm{m}\end{array}$ & $\begin{array}{c}D, \\
\mathrm{dbar} / \mathrm{m}\end{array}$ \\
\hline $\mathrm{H}$ & $3.629 \times 10^{-5}$ & $1.319 \times 10^{-3}$ & $1.802 \times 10^{-3}$ & 1.0053 \\
$\mathrm{I}$ & $2.1 \times 10^{-5}$ & $1.312 \times 10^{-3}$ & $1.07 \times 10^{-3}$ & 1.0057 \\
\hline
\end{tabular}

$30^{\circ}$ clockwise rotated from geographic coordinates. Off Saint Augustine, Florida, observed mean current in the Gulf Stream is aligned with the local topography $\left(018^{\circ} \mathrm{T}\right.$; Lee and Waddell [1983]), and we assume that the same situation prevails off Savannah, Georgia. The velocity component $u$ was then positive in the offshore direction $\left(120^{\circ} \mathrm{T}\right)$, while $v$ was positive in the northward longshore direction $\left(30^{\circ} \mathrm{T}\right)$. The wind velocity, $\mathbf{U}$, was used to compute $\mathbf{U}|\mathbf{U}|$ proportional to wind stress. Weisberg and Pietrafesa [1983] show that winter wind speed over the shelf is approximately double that at the coast. But both this factor and a drag coefficient were omitted, since their values are uncertain and have no effect on the principal quantities to be calculated (coherences and correlations). We will refer to $\sigma=\mathbf{U}|\mathbf{U}|$ as "wind stress."

At all four stations bottom pressure was measured with Paroscientific Digiquartz pressure sensors (220-psi models at stations $E$ and $F$, and 900-psi models at stations $H$ and I). Bottom temperatures were measured at these stations and used to correct for the slight temperature sensitivities of these pressure sensors and of the instrument quartz oscillator time bases.

Time series of bottom pressure, and of acoustic travel time prepared in the usual way [Watts and Rossby, 1977], were

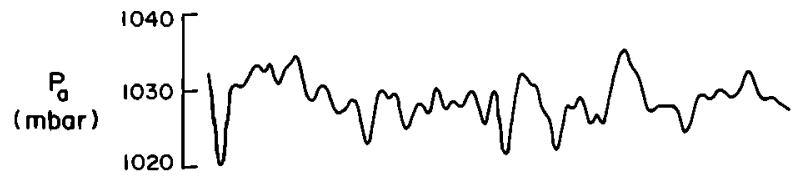

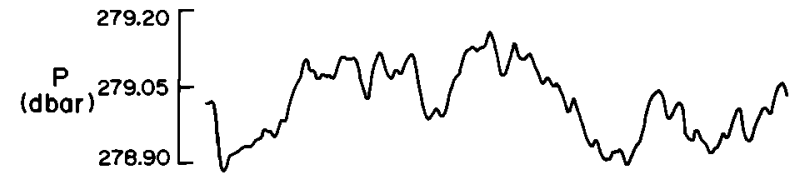

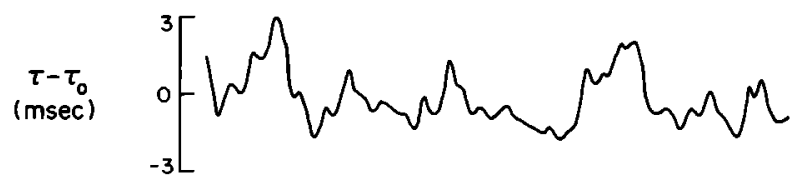

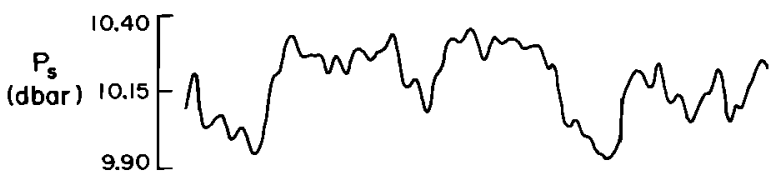

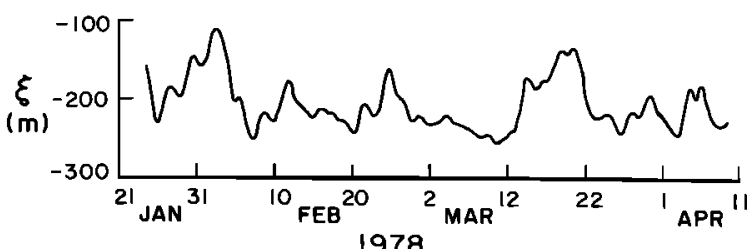

1978

Fig. 2. Subtidal time series of (from top) atmospheric pressure, bottom pressure, acoustic travel time (mean removed), computed subsurface pressure, and computed $16^{\circ} \mathrm{C}$ isotherm depth at site $\mathrm{H}$. 

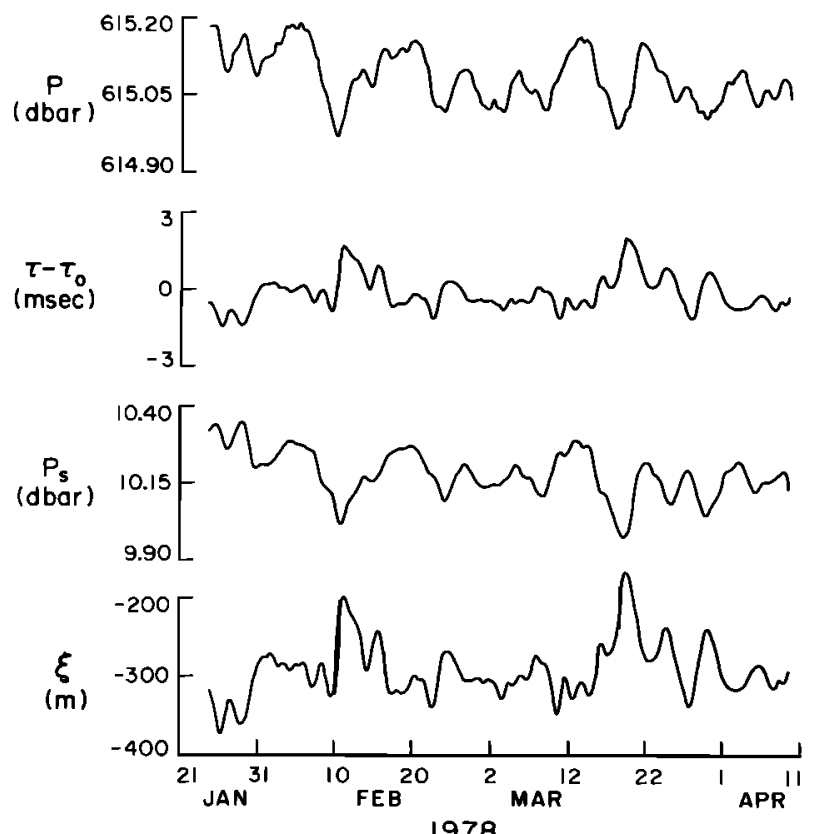

1978

Fig. 3. Subtidal time series of (from top) bottom pressure, acoustic travel time (mean removed), computed subsurface pressure, and computed $15^{\circ} \mathrm{C}$ isotherm depth at site $\mathrm{I}$.

low-pass filtered and subsampled as hourly data similarly to the current data. Tide signals were removed from these hourly current, acoustic travel time, and bottom pressure time series using Munk and Cartwright's [1966] response method. All the data were truncated to a common 1900-hour interval beginning January 22, 1978, 1300 UT.

\subsection{Quantifying the Gulf Stream Position}

Using vertical round-trip acoustic travel time $(\tau)$ through the total water column as a measurement of the main thermocline elevation $(\xi)$ was first suggested by Rossby [1969]. He pointed out that a tight linear relation exists between $\tau$ and $\xi$ in the Sargasso Sea. This principle was later used by Watts and Rossby [1977] to monitor depth variations of the main thermocline in the MODE area, and by Watts and Johns [1982] to monitor Gulf Stream position downstream of Cape Hatteras.

The inverted echo sounder is a bottom mounted instrument which measures and records the travel time of an acoustic pulse from bottom to the surface and back. Fluctuations of acoustic travel time $(\tau)$ depend on changes in elevation of the sea surface $(\eta)$ and of the thermocline $(\xi)$. To separate these parameters, bottom pressure measurement capability was added to the IES by Watts and Wimbush [1981], and the following linear model was suggested to separate $d \xi$ and $d \eta$ :

$$
\begin{aligned}
& d \tau=A d \xi+B d \eta \\
& d P=C d \xi+D d \eta
\end{aligned}
$$

With $A, B, C, D$ constant, integration gives

$$
\begin{gathered}
\tau-\tau_{0}=A\left(\xi-\xi_{0}\right)+B \eta \\
P-P_{a}-P_{0}=C\left(\xi-\xi_{0}\right)+D \eta
\end{gathered}
$$

where $P_{a}$ is atmospheric pressure, $\tau_{0}$ and $P_{0}$ are the mean values of $\tau$ and $P-P_{a}, \xi_{0}$ is the mean elevation of the main thermocline, and the sea surface elevation is assumed to have zero mean. Hydrographic data taken near the IES site during the mooring period are used to infer the elevation $\xi$ of a particular isotherm in the thermocline. Substituting in (2) this value of $\xi$ together with the simultaneously observed $\tau$ and $P$, $\eta$ is eliminated and the value of $\xi_{0}$ obtained. Thus knowing the four coefficients $(A, B, C, D), \xi$ and $\eta$ can be easily computed from measurements of $\tau$ and $P$.

In our study, the coefficients $A, B, C, D$ were evaluated from hydrographic stations taken over several years in the vicinity of each station. $A$ and $C$ were estimated by linearly regressing $\tau$ and $P-P_{a}$ with $\xi$, where $\tau$ and $P-P_{a}$ (travel time and hydrostatic pressure for each hydrographic station) were computed from the temperature and salinity profiles, and $\xi$ was the observed main thermocline elevation at the station. Several isotherms from $13^{\circ} \mathrm{C}$ to $18^{\circ} \mathrm{C}$ were tested as representing the thermocline. The $15^{\circ} \mathrm{C}$ isotherm had the highest correlation of its depth with $\tau$, and was therelore used to represent the main thermocline at station $\mathrm{I}$. At $\mathrm{H}$, however, the bottom temperature was occasionally warmer than $15^{\circ} \mathrm{C}$ and therefore the $16^{\circ} \mathrm{C}$ isotherm was used. $B$ and $D$ were determined from the average sound speed and water density computed from the same set of hydrographic stations. The estimated coefficients are given in Table 2 . There could be a seasonal effect on these coefficients, but in subdividing the data by season we could not discern a significant variation.

The reference level of the thermocline $\left(\xi_{0}\right)$ for station $\mathrm{H}$ was computed from (2) using an expendable bathythermograph (XBT) profile taken during the mooring period at site $\mathrm{H}$. Unfortunately, the corresponding XBT taken at site I was lost, so adjacent XBT stations were used with corrections for their geographical positions.

For simplicity of interpretation, $\xi$ was taken to be proportional to Gulf Stream lateral displacement. The slope of the thermocline was omitted since its value is uncertain and the principal quantities to be calculated (coherences and correlations) are unaffected by its value. We will refer to $\xi$ as "Gulf Stream displacement."

\section{Results}

The resulting records of acoustic travel time, bottom pressure, computed main thermocline elevation, and subsurface pressure $\left(P_{s}=P_{a}+\rho_{0} g \eta\right)$ are shown in Figures 2 and 3 for sites $H$ and $I$, respectively. Also shown in Figure 2 is the atmosphere pressure at Savannah. Records of coastal wind speed and currents are presented in Figure 4. Only three current records are shown, since the upper current meter at mooring $\mathbf{F}$ lailed to measure the current direction correctly. The first-order statistics of hourly time series are given in Table 3. From Figure 4 and Table 3 it is clear that the longshore current is the more energetic component at all three current meters. In this study we focus our attention on this longshore component.

For the middle shelf mooring, F, current is visibly correlated with wind in the longshore direction. Similarly, visual correlation exists between records from the two lower current meters, FBOT and EBOT. However, the relation between upper and lower current meter records from the outer shelf mooring, $\mathrm{E}$, is not obvious.

The interrelationships of these various hourly time series were investigated though spectral analysis using the method of faded overlapping segments described by Groves and Hannan [1968]. A 300-point triangular window was used with "degree of overlap" $a=2 / 3$, i.e., the displacement of two adjacent segments is 100 data points. The resulting frequency interval of 


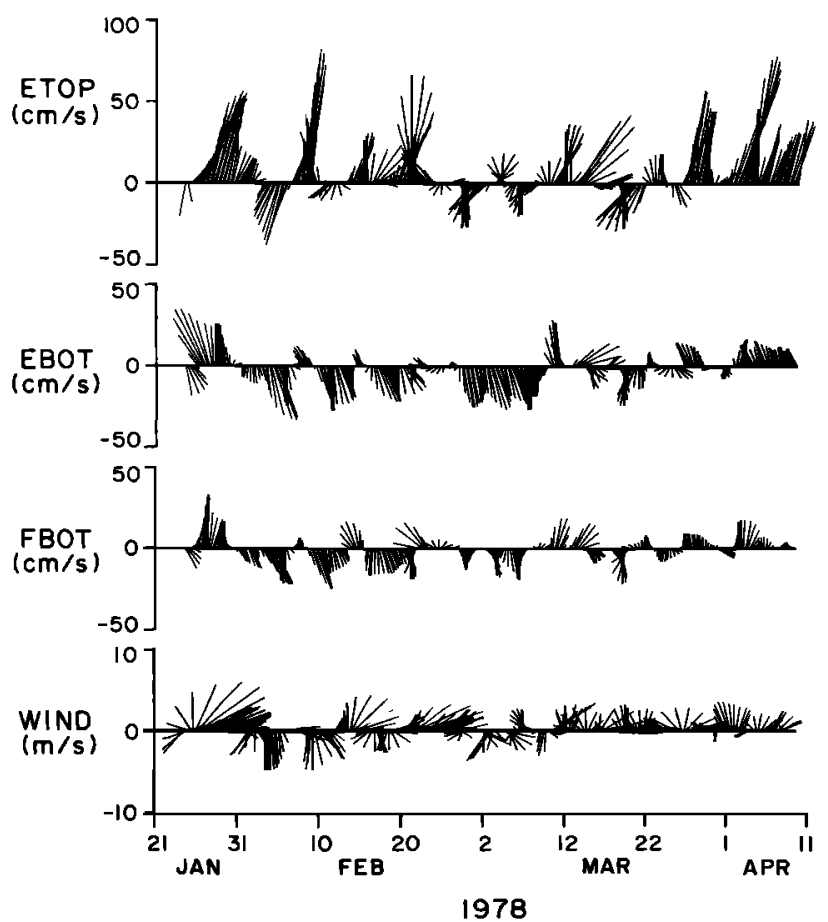

Fig. 4. Subtidal time series of rotated current records and Savannah wind. Current toward $30^{\circ} \mathrm{T}$ is upward. Stick interval, 6 hours.

the analysis is $0.08 \mathrm{cpd}$ : for example, the 12.5-day band refers to a band from 8.3 to 25 days. Significant features of the spectra at frequencies lower than $1 \mathrm{cpd}$ are discussed below.

Longshore current spectra for all three locations (ETOP, EBOT, and FBOT) show that the largest fluctuations occurred at periods longer than 5 days. The FBOT and EBOT spectra all show a most energetic peak in the 12.5-day band, while the ETOP spectrum shows a broader peak at 5-25 days (Figure 5a). The longshore current spectrum at ETOP is more energetic than at FBOT and EBOT, and this suggests a strong Gulf Stream effect in the upper layer at the shelf break, related to fluctuations in the Gulf Stream frontal structure. Coherences and phases between longshore currents from ETOP and EBOT, FBOT and EBOT are shown in Figure 5. Current at ETOP is coherent with that at EBOT for periods longer than 3.6 days, with the highest peak at 6.3 days. Another coherence peak appears at around 2.5 days. The relative phases are almost indistinguishable from zero at periods longer than 3 days. Currents at the two bottom locations (EBOT, FBOT) are coherent with one another through almost the entire subtidal band, and the coherence is higher throughout this band than the vertical coherence at site E. For periods longer than 2 days, FBOT leads EBOT by about $20^{\circ}$ in phase. Thus the current at EBOT appears to be more strongly related to current at the middle shelf than to current at ETOP, suggesting different driving dynamics for the upper and lower layers at the shelf break.

Autospectra, coherence-squared, and relative phase of the wind stress components are presented in Figure 6. Longshore wind shows a well-defined energy peak at 12.5 days, and a less significant peak at 2 days' period. The cross-shore wind shows a similar peak at 12.5 days and has another significant peak at 2.5 days. The low-frequency energy of the $U$ component is greater than that of the $V$ component. The two wind stress components are significantly coherent at periods longer than 1 week and at 2-3 days, with $V$ leading $U$ by 7 hours.

As shown in Table 1, the IES at site $H$ was located at the 265-m isobath, approximately beneath the mean Gulf Stream surface front, and the other IES at site I was located at the $589-\mathrm{m}$ isobath, roughly beneath the mean surface current core of the Gulf Stream. Both instruments responded to Gulf Stream lateral movement. In the power spectra of Gulf Stream displacement an energetic 12.5-day peak appears both at $\mathrm{H}$ and I, while an additional less energetic 2.5-day peak appears only at offshore station I (Figure 7). The coherence between the two stations is significiant only at low frequencies (period $>5$ days) with the phase difference near zero. It appears that at lower frequencies meandering of the Gulf Stream produces a correlated "bulk" response of the main thermocline at $\mathbf{H}$ and I, but at higher frequencies (periods less than 5 days) the fluctuations are primarily local processes. Analysis indicates that Gulf Stream displacement measured at $\mathrm{H}$ was more coherent with shelf currents than that at $I$, so the measurement at $\mathrm{H}$ was the one used in this study. A more detailed comparison of measurements at $\mathbf{H}$ and $I$ with shelf current at $E$ is given in a separate paper [Li and Wimbush, 1985].

Also shown (Figure 8) are the coherence and phase of Gulf Stream displacements and subsurface pressure at site $H$ and at site I. The coherences are generally high and the phase differences are close to $180^{\circ}$ consistent with baroclinic compensa-

TABLE 3. First-Order Statistics of Hourly Data

\begin{tabular}{lcccccc}
\hline Station & Parameter & Unit & Minimum & Maximum & Mean & $\begin{array}{c}\text { Standard } \\
\text { Deviation }\end{array}$ \\
\hline Savannah & $U$ & $\mathrm{~m} / \mathrm{s}$ & -6.7 & 11.1 & 0.9 & 3.0 \\
& $V$ & $\mathrm{~m} / \mathrm{s}$ & -6.7 & 8.7 & 0.4 & 2.5 \\
FBOT & $u$ & $\mathrm{~cm} / \mathrm{s}$ & -27.4 & 20.4 & 1.6 & 6.2 \\
& $v$ & $\mathrm{~cm} / \mathrm{s}$ & -32.4 & 40.1 & -2.3 & 11.8 \\
ETOP & $u$ & $\mathrm{~cm} / \mathrm{s}$ & -34.5 & 69.4 & 3.3 & 13.3 \\
& $v$ & $\mathrm{~cm} / \mathrm{s}$ & -54.8 & 120.5 & 13.3 & 28.1 \\
EBOT & $u$ & $\mathrm{~cm} / \mathrm{s}$ & -29.7 & 39.8 & 0.7 & 8.4 \\
& $v$ & $\mathrm{~cm} / \mathrm{s}$ & -39.4 & 44.0 & -4.2 & 15.5 \\
H & $P_{s}$ & $\mathrm{dbar}$ & 9.88 & 10.40 & 10.19 & 0.15 \\
& $\xi$ & $\mathrm{m}$ & -272.1 & -87.4 & -201.5 & 35.0 \\
I & $P_{s}$ & $\mathrm{dbar}$ & 9.72 & 10.41 & 10.18 & 0.13 \\
& $\xi$ & $\mathrm{m}$ & -429.8 & $7.5^{*}$ & -284.7 & 51.0 \\
\hline
\end{tabular}

Here, wind $(U, V)$ and current $(u, v)$ coordinates are aligned $\left(30^{\circ}, 120^{\circ}\right) . P_{s}$, subsurface pressure; $\xi$, main thermocline elevation.

*At the very end of the observation period a cold eddy passed over site $\mathrm{I}$, raising the $15^{\circ} \mathrm{C}$ isotherm and causing it to intersect the surface (not visible in Figure 3 because of truncation by the low-pass filter). 


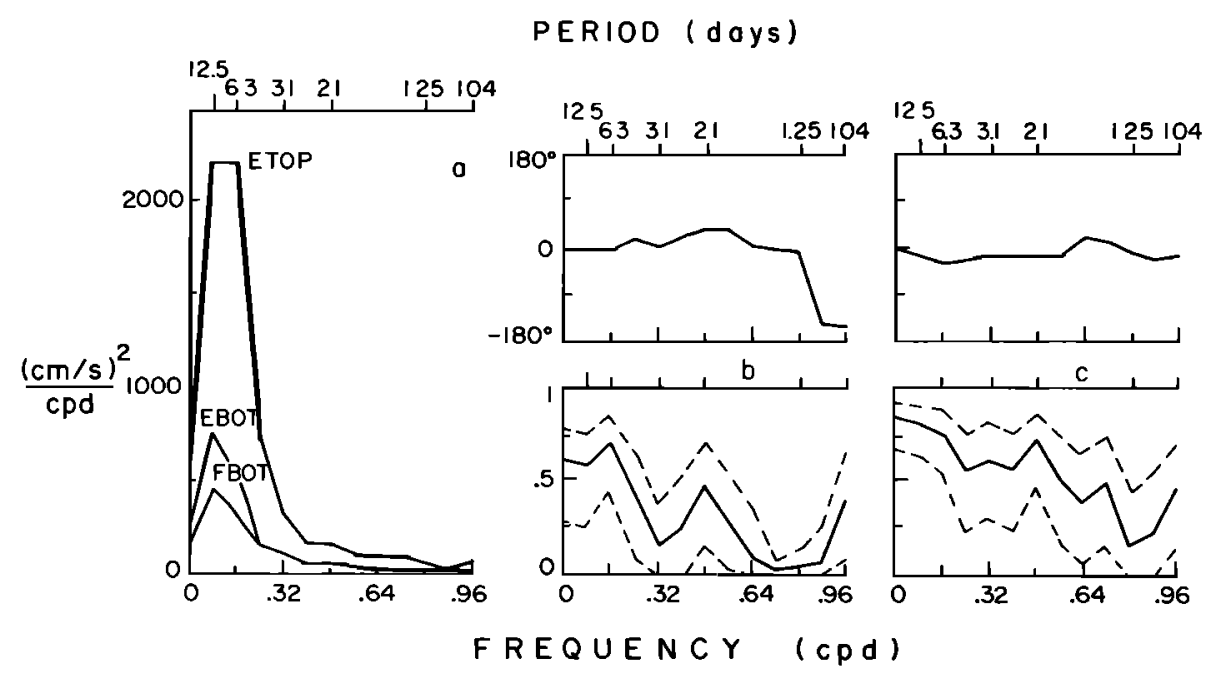

Fig. 5. (a) Autospectra of longshore currents. Coherence-squared (lower panel) and relative phase (upper panel) from (b) ETOP and EBOT and from (c) FBOT and EBOT. Frequency interval, 0.08 cpd; effective bandwidth, 0.14 cpd; 23 degrees of freedom. Positive phase implies that the second time series leads the first; dashed lines show the $95 \%$ confidence interval for coherence-squared.

tion. The coherences at site $\mathbf{H}$ are generally somewhat higher than at site $I$.

The coherences of wind components and Gulf Stream displacement are insignificant (not shown), indicating no direct relation between wind and Gulf Stream meanders.

With wind stress and Gulf Stream displacement monitored in the manner described, it was possible to examine the relationship of shelf current variability to Gulf Stream meandering and wind forcing, as a function of frequency. The fruits of this examination are discussed in the following section.

\section{Discussion}

\subsection{Longshore Current Variability on the Middle Shelf}

In this section we discuss the causes of longshore current variability at the middle shelf (site F, 45-m isobath). Since the direction sensor at FTOP failed, our discussion is limited to the FBOT record.

The direct coherences of longshore current at FBOT with each potential forcing parameter (wind stress components, and Gulf Stream displacement) are presented in Figure 9. The cur-

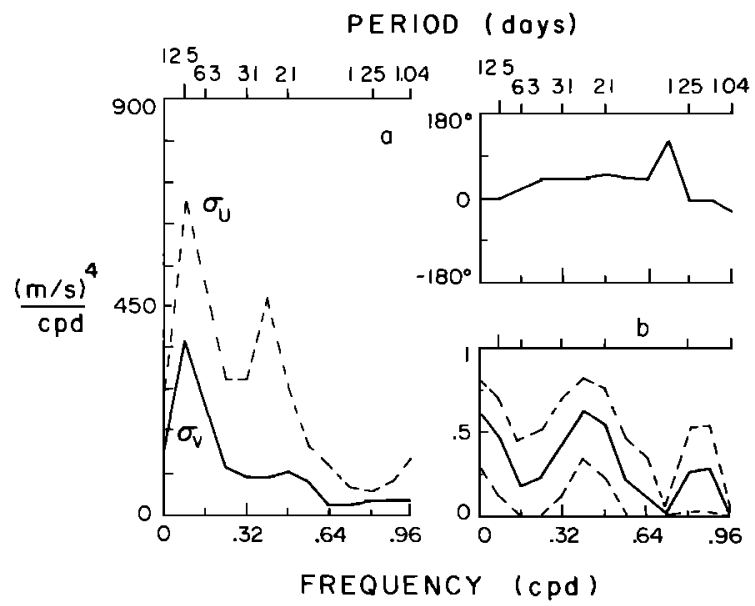

Fig. 6. Autospectra, phase, and coherence-squared of cross-shore and longshore Savannah wind stress components. See Figure 5 legend for details. rent was highly coherent with longshore wind at periods longer than 2 days with 13 hours time lag, and coherent with cross-shelf wind at periods longer than 1.4 days (except for the 6.3 day band), with time lag 6 hours. No significant coherent peak appears between current and Gulf Stream displacement.

A three-input linear model was used to model the forcing of longshore shelf current fluctuations by wind stress components and Gulf Stream displacement in the frequency domain. In the method used [Bendat and Piersol, 1971; Groves and Hannan, 1968], linear regression was performed for each frequency band, partial coherences and phases of longshore current with wind stresses and Gulf Stream displacement were computed, and then the multiple coherence of the system was estimated to see how much of the longshore current variability can be accounted for with these three variables.

Results of the three-input linear regression analysis are given in Figure 10. At low frequencies, note that the direct coherence between longshore current and cross-shore wind is moderately high, but the partial coherence is low. This indicates that low frequency longshore current was dominated by longshore wind rather than cross-shore wind. The apparent

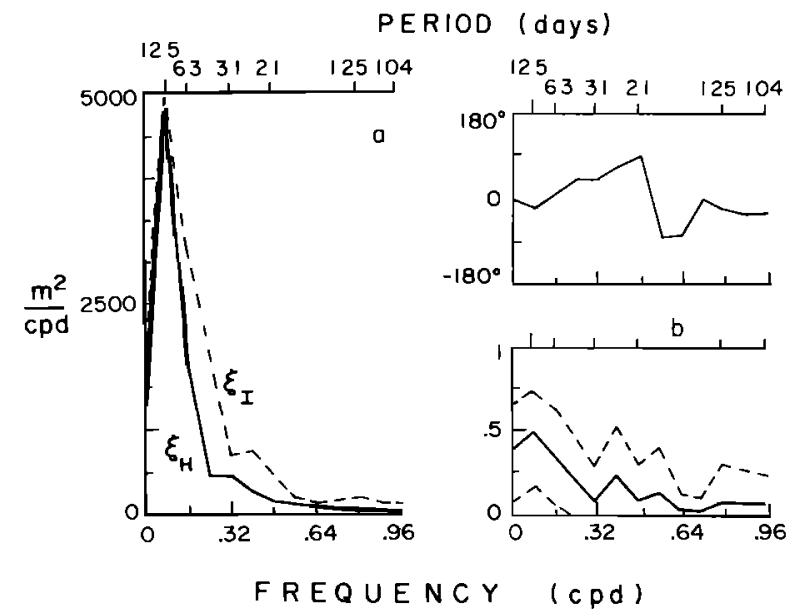

Fig. 7. Autospectra, phase, and coherence-squared of thermocline displacement records from IES moorings $\mathrm{H}$ and I. See Figure 5 legend for details. 

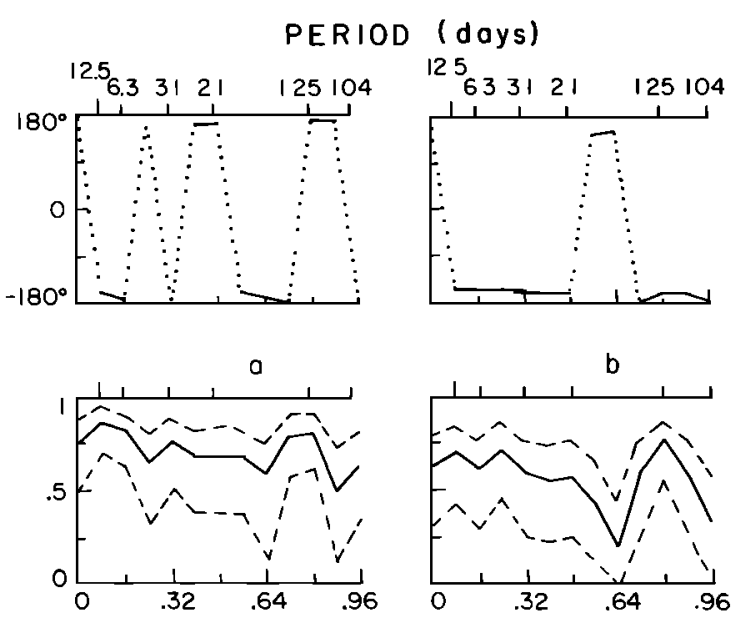

FREQUENCY (cpd)

Fig. 8. Phase and coherence-squared of computed thermocline displacement and subsurface pressure for $(a)$ site $\mathrm{H}$ and $(b)$ site $\mathrm{I}$. See Figure 5 legend for details.

high direct coherence with cross-shore wind came from the high coherence between the wind components themselves. However, partial coherence analysis does show that both longshore and offshore winds contribute to the longshore current fluctuations: at long periods the fluctuations are dominated by longshore wind, while offshore wind contributes at periods from 1.3 to 4 days. A partial coherence peak of longshore current at FBOT with Gulf Stream position appears at the 12.5-day period suggesting occasional penetration of Gulf Stream frontal variability onto the middle shelf. However, this peak is not quite significantly distinguishable from zero at the 95\% confidence level.

These findings indicate that, during the winter, mid-shelf $(F)$ longshore current is not significantly related to Gulf Stream displacement and is strongly dependent on local wind forcing at periods longer than 1.3 days. The middle shelf is effectively isolated from the influence of propagating Gulf Stream disturbances by the broad shallow Georgia shelf. Longshore current variability is mainly driven by longshore wind at periods longer than 4 days, in agreement with previous observations
[Lee and Brooks, 1979; Lee et al., 1981]. Longshore wind produces Ekman transport causing the sea level to set-up (or set-down) and thus driving a geostrophic longshore flow, a response similar to that observed in the Middle Atlantic Bight and other U.S. shelves (see Allen et al. [1983] for summaries and further references). It has been shown that a steady state diagnostic vorticity balance model can predict flows well in the mid-shelf region off Georgia for time scales of 2 weeks or longer [Lee et al., 1982].

The contribution from cross-shore wind has been noted by Lee and Brooks [1979]. They found that when wind stress was primarily longshore, most of the observed longshore flow was in geostrophic balance, but when wind stress was not longshore, geostrophic balance only accounted for $25 \%-50 \%$ of the flow. Partial coherence analysis of our data indicates that the cross-shore wind effect is generally stronger than that of longshore wind in a higher frequency band (1.3-4 days' period). This band coincides with an energetic peak in the cross-shore wind spectrum centered at 2 days. Since mean and standard deviation of cross-shore wind are somewhat larger than those of longshore wind in this area during the period of observation (Table 3), it may be that the cross-shore wind effect is more pronounced on the Georgia shelf than in other areas along the SAB. The dynamics of the cross-shore wind contribution is not clear. Spectral analysis shows that crossshore wind and measured cross-shore currents are $180^{\circ}$ out of phase (not shown). Certain strong offshore wind events are apparently associated with strong onshore flow (e.g., February 21 in Figure 4). Since the current meters in this experiment are believed to be located below the surface Ekman layer [Lee and Brooks, 1979], it is likely that the surface water is driven seawards by the offshore wind impulse, and, because of the coastal constraint, creates an onshore pressure gradient. This pressure gradient then drives a deeper return flow which is recorded by the current meters. Calculation indicates that the observed offshore wind stress during these events is strong enough to drive a surface Ekman transport which is balanced by the observed return flow. When offshore wind reaches its maximum, longshore current begins to increase, as a geostrophic response to the cross-shore pressure gradient. Figure 6 shows a strong 2.5-day energy peak in the cross-shore wind stress, 5 times as strong as the long-shore stress at this period.
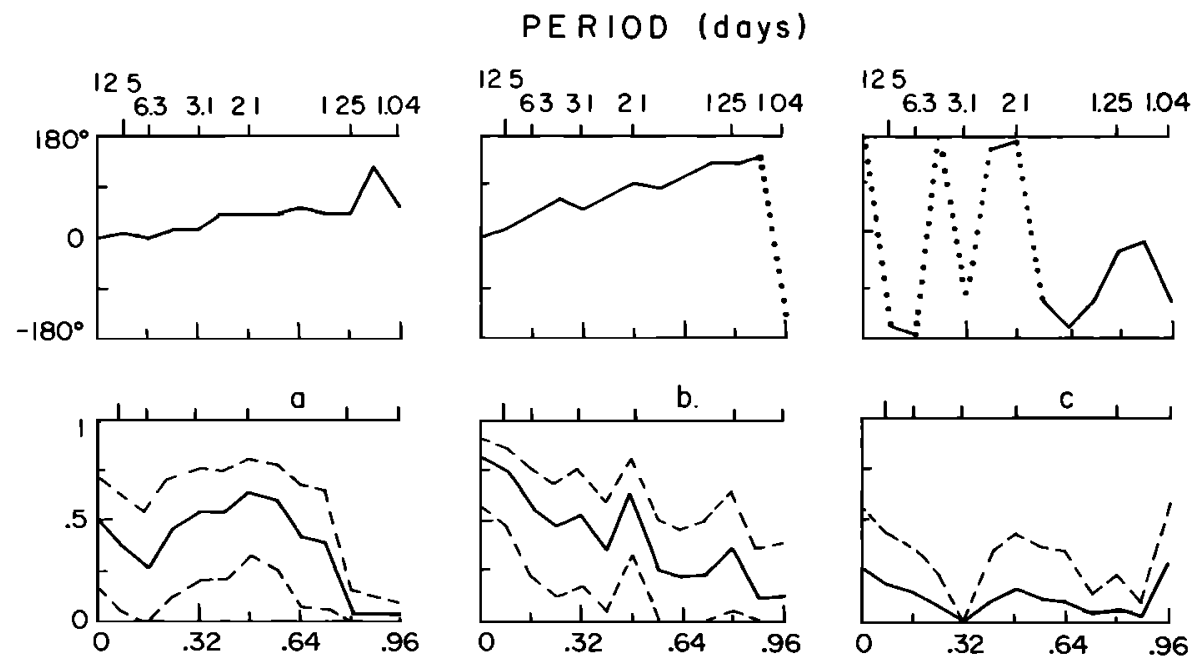

Fig. 9. Direct coherence-squared and phase of mid-shelf longshore current at FBOT with (a) cross-shore wind stress, (b) longshore wind stress, and (c) Gulf stream displacement. See Figure 5 legend for details. 

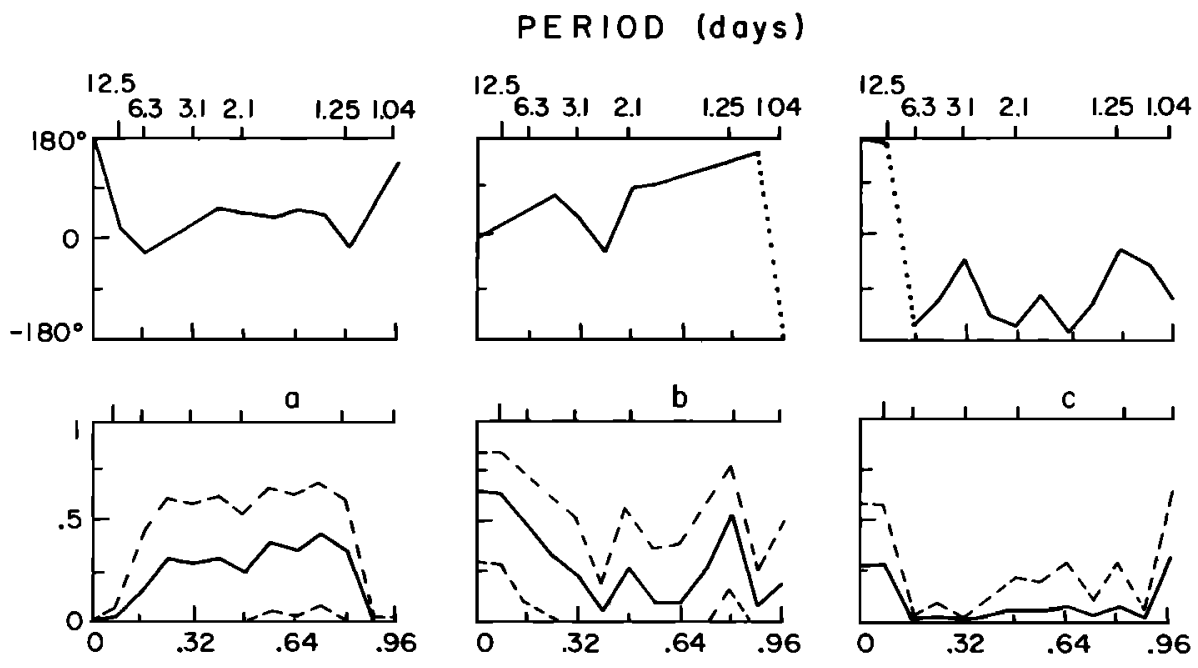

FREQUENCY (cPd)

Fig. 10. Same as Figure 9, but for partial coherence-squared and phase (19) degrees of freedom for the residual spectra).

Off Saint Augustine, Florida, Lee et al. [1984] found that the momentum imparted to the total water column by the crossshore wind was a significant part of the fluctuating momentum balance at both the $28-$ and $40-\mathrm{m}$ isobaths. Also the cross-shore scale of the continental shelf being much smaller

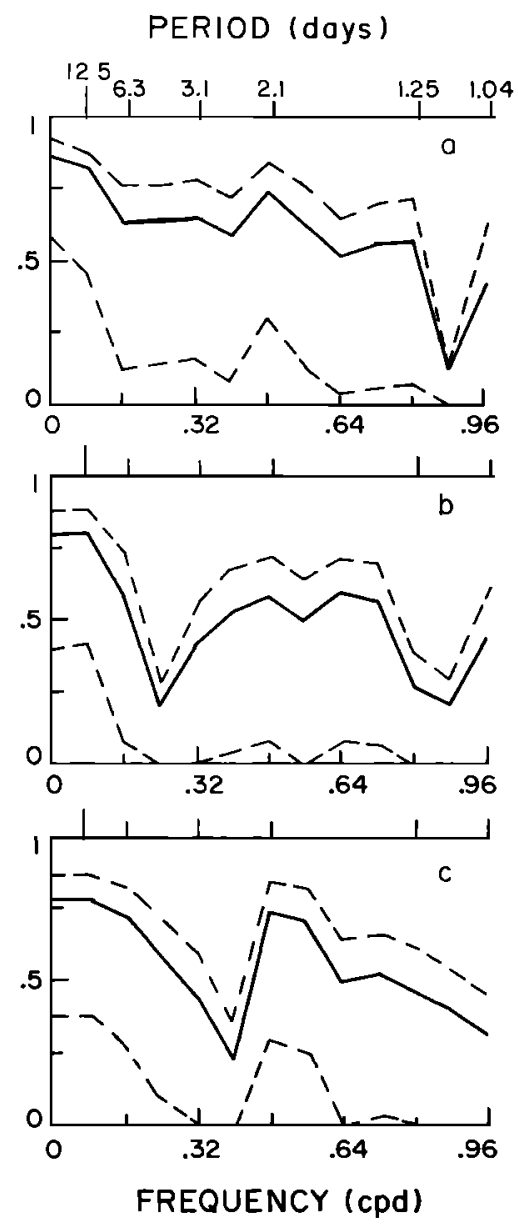

Fig. 11. Multıple coherence-squared of longshore current with all three forcing factors (both wind stress components and Gulf Stream displacement): (a) FBOT, (b) ETOP, and (c) EBOT. than the longshore scale, it may be that the current responds preferentially to cross-shore wind at higher frequencies.

Multiple coherence (Figure 11a) of mid-shelf longshore current with wind stress components and Gulf Stream displacement is high at periods longer than 8 days and significant at periods of 1.3-8 days, but almost none of this multiple coherence derives from the Gulf Stream input.

\subsection{Longshore Current Variability at the Shelf Break}

In this section we discuss the longshore current variability at the shelf break (site E, 75-m isobath). Since the coherence between currents measured at ETOP and EBOT is not high (Figure $5 b$ ), we consider these currents separately; and since current fluctuations are stronger at ETOP than at EBOT (Figure 4), we concentrate our attention initially on the ETOP current record.

At the outer-shell mooring, E, the upper current meter record shows a longshore current, $v$, oscillating around a mean of $13.3 \mathrm{~cm} / \mathrm{s}$, with standard deviation of $28.1 \mathrm{~cm} / \mathrm{s}$. Both the mean and the standard deviation are larger than at the $45-\mathrm{m}$ isobath. Subtidal current fluctuation energy is concentrated at low frequencies (periods from 5 to 25 days; Figure 5).

The forcing dynamics of longshore current variability over the outer shelf are complicated. Previous investigations indicate that the low-frequency current variability at the outer continental shelf along the South Atlantic Bight results from the combined effects of variable atmospheric and Gulf Stream forcing. As the shelf break is approached, the effects of Gulf Stream meanders and frontal eddies become stronger and relatively more important [Lee and Brooks, 1979; Lee et al., 1982; Lee and Atkinson, 1983].

Our data show that Gulf Stream and wind forcing both contribute to low-frequency current variability at the outer shelf mooring $E$, the Gulf Stream influence being much stronger than at mooring F (45-m isobath). The direct coherence and phases between longshore current fluctuation at ETOP and three different forcing factors are presented in Figure 12. Longshore current is highly coherent with Gulf Stream displacement in the 12.5-day band, while lower coherence peaks appear at 2 and 1.5 days. The phase differences are close to $180^{\circ}$ for all frequency bands. Longshore current is 

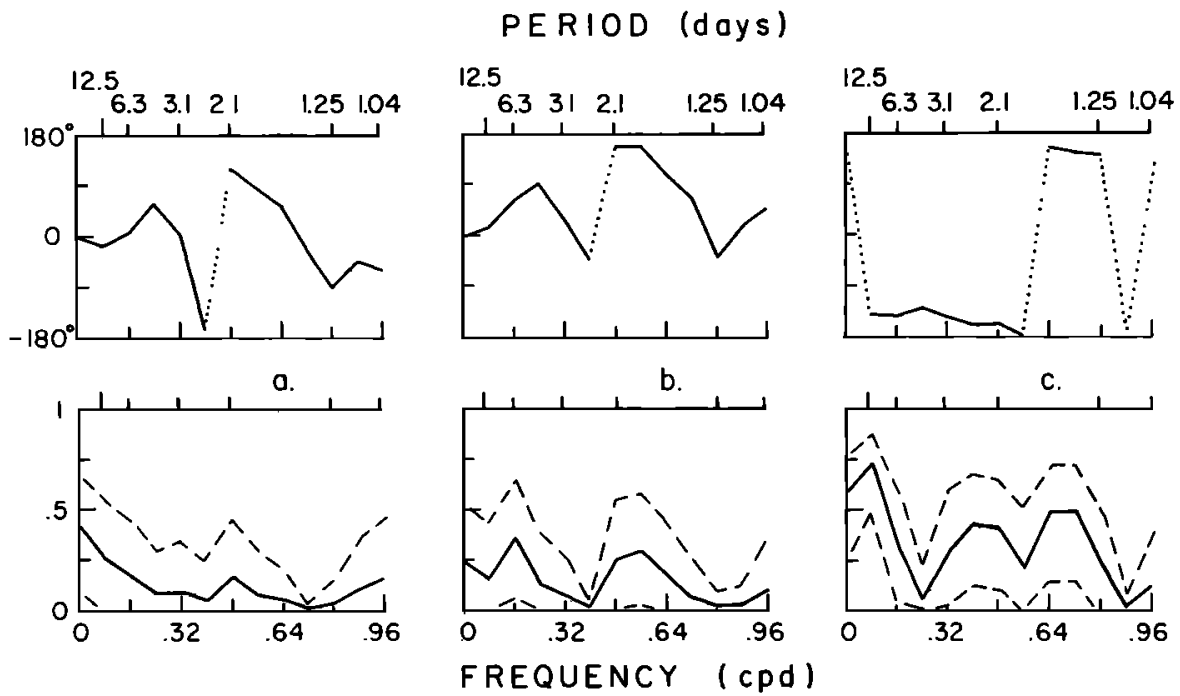

Fig. 12. Same as Figure 9, but for ETOP.

marginally coherent with longshore wind stress at 6.3 days and at around 2 days. Cross-shore wind stress also shows coherence at very low frequencies.

Linear regression was performed using a three-input linear model, similar to that for the middle shelf, to determine the relationship of the longshore current to Gulf Stream displacement and long- and cross-shore wind stresses. Results of the analysis are shown in Figure 13. Partial coherences of longshore current with Gulf Stream displacement, longshore wind and cross-shore wind are not significantly different from the direct coherences, and we will not distinguish between them in this section's discussion of the ETOP record.

Multiple coherence of the two wind stress components plus Gulf Stream displacement (inputs) with upper water column longshore current velocity (output) is shown in Figure $11 b$. The high multiple coherence at periods longer than 5 days shows that these three inputs account for most of the longshore current variability at low frequencies, where most of the spectral energy is concentrated (Figure 5). However, there is a low-coherence band located at 2.8-5 days

4.2.1. Wind forcing. Webster [1961] observed a weekly current fluctuation over the upper continental slope off
Onslow Bay, North Carolina, and suggested that atmospheric forcing was a possible cause. Since then, efforts have been made to determine the relationship between wind forcing and current variability on the outer shelf and in the Gulf Stream frontal area along the South Atlantic Bight. Brooks and Bane [1981] found no significant subtidal correlation between longshore current fluctuations and wind over the Onslow Bay upper continental slope (200-m isobath). However, in a later paper [Brooks and Bane, 1983] they report a coherence peak at 3-4 days observed at $100-\mathrm{m}$ depth (200-m isobath) during the winter with no significant coherence at weekly periods. Lee and Mayer [1977], studying current variability along the Southeast Florida shelf, found longshore current to be marginally coherent with longshore wind at periods of 4.1 and 18.6 days and highly coherent with offshore wind at $\mathbf{3 7 . 3}$ days with lesser peaks at 9.3, 4.7, and 2.2 days. Lee and Brook's [1979] observations indicate a 5.5-day coherence peak between longshore wind and current at the $50-\mathrm{m}$ isobath off Georgia, but no such coherence at the $100-\mathrm{m}$ isobath. Marginal coherence of longshore wind with near-bottom current at 7.7 day's period at the $75-\mathrm{m}$ isobath off Saint Augustine was reported by Lee and Atkinson [1983].

\section{PERIOD (days)}
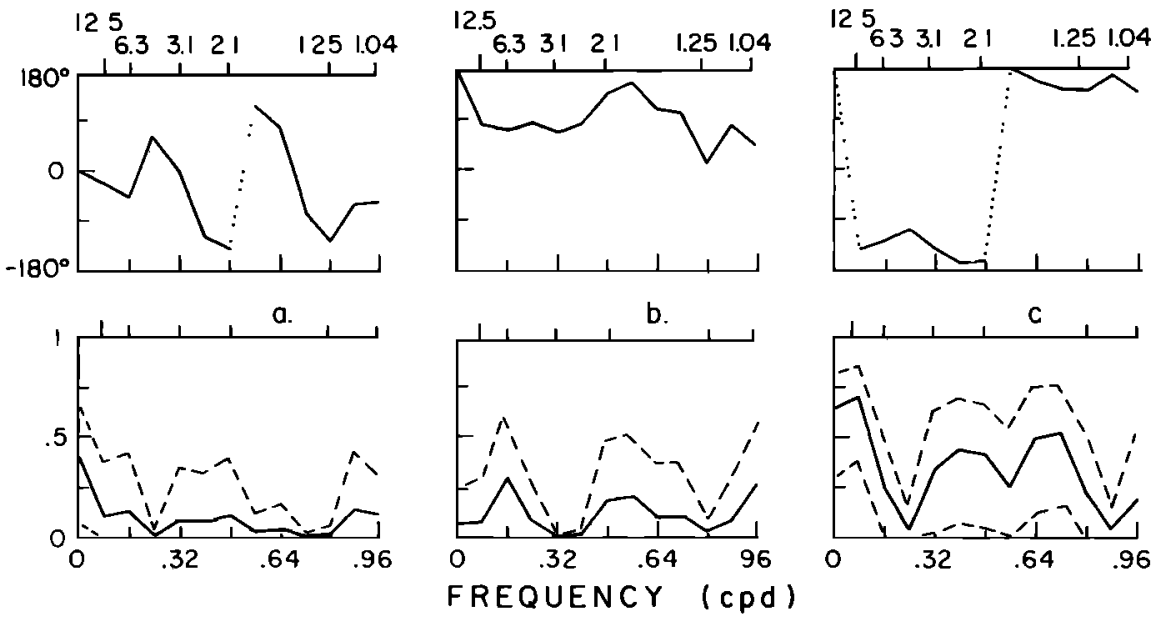

Fig. 13. Same as Figure 10, but for ETOP. 
According to these previous observations, on the outer shelf of the southeast United States, in the energetic band of meteorological fluctuations from several days to 2 weeks, coherence of current with local wind is occasionally observed but is never strong. The coherence is generally lower than the $95 \%$ significance level in the upper layer but is higher in the lower layer. Although Gulf Stream position has not been continuously monitored by previous investigators, it would appear that as the continental slope is approached, the Gulf Stream influence tends to mask the wind effect causing the lack of low-frequency wind-current coherence on the outer continental shelf and upper slope.

This account is supported by our observations at the outer shelf mooring $\mathrm{E}$. Coherence between longshore wind stress and longshore current shows peaks at 6.3 and $\sim 2$ days. It is noteworthy that a mean longshore current of $24.6 \mathrm{~cm} / \mathrm{s}$ was observed at ETOP for a 40-day period from November 10 to December 20, 1977, nearly twice as large as the $13.1-\mathrm{cm} / \mathrm{s}$ mean of the ETOP record discussed here. This suggests long term ( $>1$ month) variability of the Gulf Stream position off Georgia. The observed wind effects could be a function of the long-term meandering of the Gulf Stream front. When the front is close to the shelf break, Gulf Stream meanders and frontal eddies would dominate the low-frequency variability at periods of several days to one month; when the front is located further offshore, the Gull Stream influence is less and the effect of wind forcing would become more evident.

4.2.2. Gulf Stream forcing. The most significant coherence peak between ETOP longshore current and the Gulf Stream is in our lowest frequency band centered at 12.5 days. This is the most energetic band of the Gulf Stream displacement records at both $\mathrm{H}$ and $\mathrm{I}$ moorings. Furthermore, it is the band of maximum coherence between these two records (Figure 7). It appears to be the characteristic frequency band of Gulf Stream wavelike meanders off Georgia during the mooring period. As mentioned above, the phase difference between Gull Stream displacement and longshore current is very close to $180^{\circ}$. This means that when the Gulf Stream moves onshore (i.e., thermocline deepens, $\xi$ decreases), it causes increased northward flow at the shelf break, and vice versa. A similar process has been observed further offshore at Onslow Bay, North Carolina, by Brooks and Bane [1981] and Bane et al. [1981], off Georgia by Lee and Brooks [1979], and off Saint Augustine, Florida, by Lee and Atkinson [1983].

Various processes along the Gulf Stream western edge can affect the longshore current at the outer continental shelf, in particular wavelike meanders and Gulf Stream frontal eddies. Brooks and Bane [1981] and Bane et al. [1981] find that off Onslow Bay, longshore current fluctuations over the upper continental slope are related to Gulf Stream wavelike meanders. The increase in downstream velocity is associated with an approaching shoreward meander crest, followed by a rapid velocity decrease after the crest's passage.

The effect of Gulf Stream cyclonic frontal eddies has been investigated by Lee et al. [1981] and Lee and Atkinson [1983] in detail. They suggest that northward propagating frontal eddies account for a significant part of the low-frequency variability on the outer shelf and find that the onset of each disturbance is followed by decreasing northward current speed and temperature. Some studies, however, suggest anticyclonic current rotations inside warm filaments [Pietrafesa and Janowitz, 1980; Pietrafesa, 1983; Chew, 1981] that would change the picture of frontal eddies.

Coherence analysis of our data reveals that upper water column current fluctuations at the shelf break are directly related to the Gulf Stream displacement, measured at the $265-\mathrm{m}$ isobath, for periods longer than 8 days, with a peak at 12.5 days (Figure 13). The high coherence in the 12.5-day band and the simple phase relationship strongly suggest that the wavelike lateral "bulk" meandering of the Gulf Stream is the primary source of observed Gulf Stream forcing. This is confirmed by the 12.5-day coherence peak for Gulf Stream displacement measured at stations $\mathbf{H}$ and $\mathbf{I}$.

It is obvious, however, that frontal eddies, especially filaments on the eddies' inshore edges have an important influence on the currents over the outer shelf. When an eddy passes by, the southward flowing filament decreases the longshore current, $v$. As observed by Lee et al. [1981], some frontal eddies extend to several hundred meters depth all along the slope. In our observations a strong current reversal occurred from March 15 to 21 (Figure 4). During the same interval the thermocline at both sites $\mathrm{H}$ and $\mathrm{I}$ rose more than $100 \mathrm{~m}$ and then dropped back to the normal level (Figures 2 and 3). Most current reversals, however, are not associated with significant elevations in the thermocline time series; the strong current reversals of February 28 and March 6 have no corresponding indications in the IES records. This implies that the upwelled cold water in the core is from the upper $250 \mathrm{~m}$. In certain cases, however, the disturbance can extend to a depth of nearly $600 \mathrm{~m}$. Such a deep disturbance occurs in conjunction with a large-scale meander, and features a well-developed eddy with a strong upwelled cold core.

The cause of the low multiple-coherence window at 2.8-5 days is uncertain, but we think it is probably the weaker frontal eddies and their associated filaments. As discussed above, the weaker frontal eddies can directly influence outer shelf currents without significantly disturbing the thermocline over the slope. Furthermore, when eddies pass a mooring they tend to induce high-frequency (frequencies higher than the basic frequency) fluctuations in the Eulerian current measurement [Freeland et al., 1975]. Indeed, the observed lowfrequency spectral peak in current at ETOP extends to shorter periods than the corresponding peak in Gulf Stream displacement: from the 12.5-day band to the 4-day band the Gulf Stream meander energy drops about $10 \mathrm{dbar}$, while the current energy drops only 5 dbar (Figures 7 and $5 a$ ). Finally, the filaments usually have longshore length scale of $100-200 \mathrm{~km}$ with cross-shore scale of $10-30 \mathrm{~km}$, and appear to travel downstream at $30-55 \mathrm{~cm} / \mathrm{s}$ [Lee and Atkinson, 1983]. Hence they will be associated with current fluctuation periods of 2-7 days, shorter than the meander periods of $\sim 12$ days.

4.2.3. Vertical structure at the shelf break. The same analysis procedure has been applied to the longshore current record measured at EBOT, for comparison. Results are presented in Figure 14. Partial coherence of this current with Gulf Stream displacement shows a marginally significant peak at 12.5 days. Together with the reduced spectral energy at this period (Figure 5), this indicates weaker Gulf stream forcing in the lower layer at the shelf break. Partial coherence between current and wind stresses peaks at 1.4 and 6.3 days for crossshore wind, and at 1.3, 1.8, and 6.3-12.5 days for longshore wind. All peaks are lower than 0.5 (coherence-squared). These results indicate that longshore current variability at EBOT is due to a combination of different factors. At periods longer than 8.3 days, longshore wind and Gulf Stream contribute about equally, and together account for most of the overall current variability. The multiple coherence shows an extended band of significant coherence ( $>3.6$ days; Figure $11 c$ ) com- 

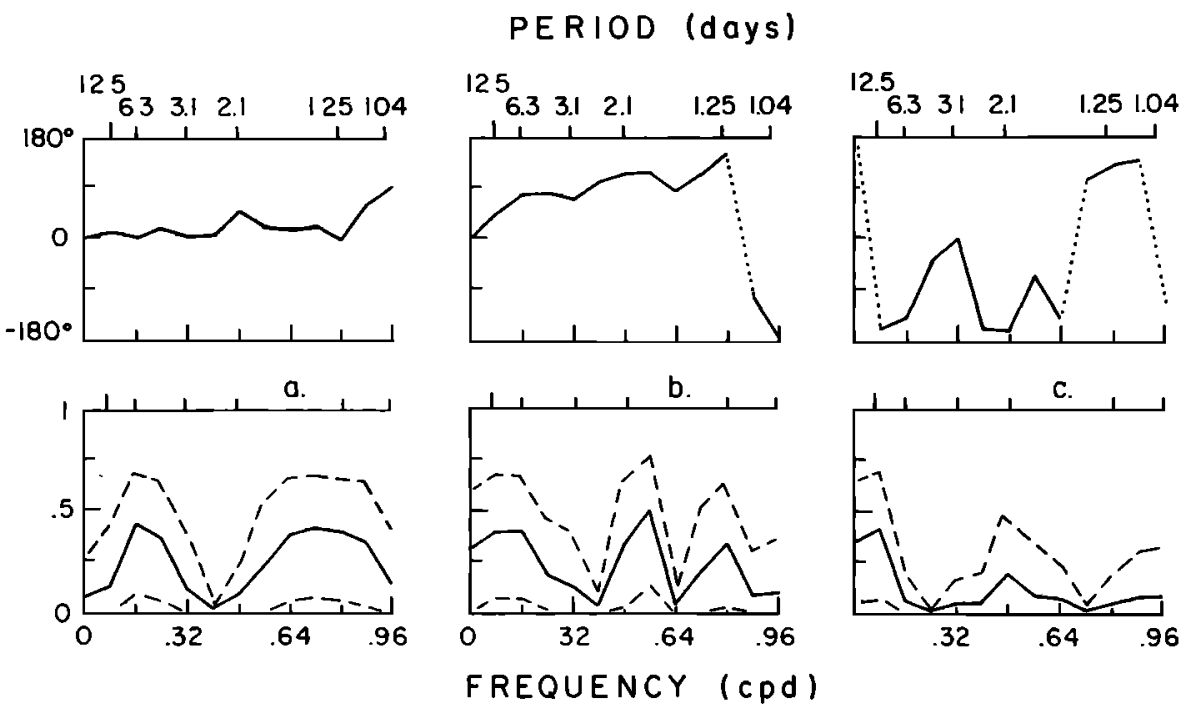

Fig. 14. Same as Figure 10, but for EBOT.

pared with that of ETOP ( $>5$ days, Figure $11 b$ ); this is mainly attributable to the wind. For the 4-day band the contribution of cross-shore wind is more important than that of the other two factors.

In general, longshore current at EBOT shows less influence from the Gulf Stream and more from the wind than that at ETOP. In contrast, it shows more influence from the Gulf Stream and less from the wind than that at Station F. Thus the EBOT record is intermediate in character between the ETOP and FBOT records. The temperature records from the ETOP and EBOT current meters often show a temperature difference between these levels of $\sim 5^{\circ} \mathrm{C}$. It seems that the Gulf Stream cyclonic front often separates the water column at the shelf break into two parts: active Gulf Stream induced current at top and modified wind driven shelf current below.

\subsection{Simplified Prediction Scheme}

In the preceding analysis, each multiple coherence-squared (Figure 11) indicates the proportion of the longshore current (v) energy that is predictable from Savannah wind stress $\left(\sigma_{v}\right.$, $\left.\sigma_{V}\right)$ and site $H$ thermocline level $(\xi)$, according to the representation

$$
\begin{aligned}
v(t)=\int_{-\infty}^{\infty} h_{v}(\tilde{t}) \sigma_{v}(t-\tilde{t}) d \tilde{t} & +\int_{-\infty}^{\infty} h_{v}(\tilde{t}) \sigma_{v}(t-\tilde{t}) d \tilde{t} \\
& +\int_{-\infty}^{\infty} h_{\zeta}(\tilde{t}) \xi(t-\tilde{t}) d \tilde{t}+e(t)
\end{aligned}
$$

where the impulse response functions, $h$, are chosen to minimize the variance of the error, $e$. The $h$ functions are obtained by Fourier transforming the corresponding transfer functions,
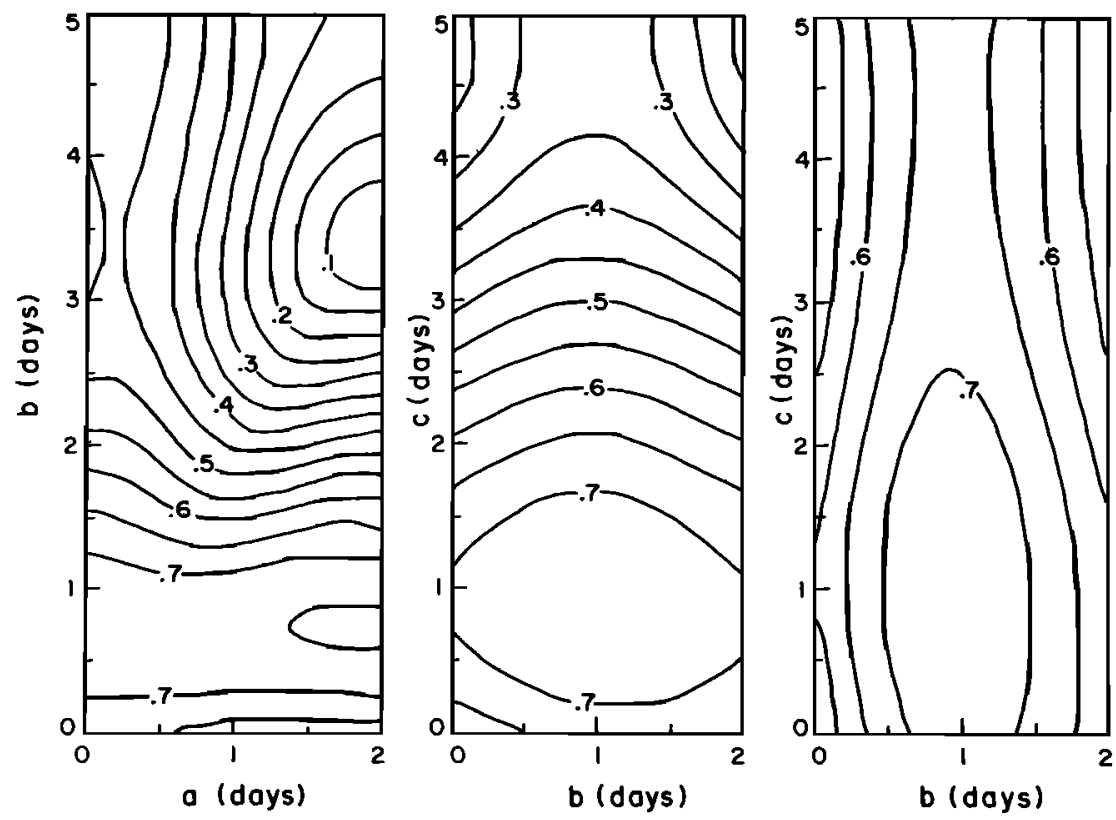

Fig. 15. Multiple-correlation coefficient $r$ of longshore current variation $v^{\prime}$ as a function of lag times on the two inputs: at FBOT, inputs $\sigma_{v}{ }^{\prime}$ and $\sigma_{v}{ }^{\prime}$ (left panel); at ETOP, inputs $\sigma_{v}{ }^{\prime}$ and $\xi^{\prime}$ (center panel); at EBOT, inputs $\sigma_{v}{ }^{\prime}$ and $\xi^{\prime}$ (right panel). 
TABLE 4. Computed Lags and Coeficients of Equation (3) for Maximum Multiple-Correlation Coefficient $r$

\begin{tabular}{|c|c|c|c|c|c|c|c|c|}
\hline Instrument & $r$ & $r^{2}$ & $\begin{array}{l}a \\
\mathrm{hr}\end{array}$ & $\begin{array}{l}b, \\
\text { hr }\end{array}$ & $\begin{array}{l}c \\
\mathrm{hr}\end{array}$ & $\begin{array}{c}A, \\
\frac{\mathrm{cm} / \mathrm{s}}{\mathrm{m}^{2} / \mathrm{s}^{2}}\end{array}$ & $\begin{array}{c}B, \\
\frac{\mathrm{cm} / \mathrm{s}}{\mathrm{m}^{2} / \mathrm{s}^{2}}\end{array}$ & $\begin{array}{c}C, \\
\frac{\mathrm{cm} / \mathrm{s}}{\mathrm{m}}\end{array}$ \\
\hline FBOT & 0.74 & 0.55 & 5 & 17 & & 0.843 & 0.707 & \\
\hline ETOP & 0.74 & 0.55 & & 25 & 20 & & 0.881 & -0.461 \\
\hline EBOT & 0.74 & 0.55 & & 22 & 24 & & 0.864 & -0.113 \\
\hline
\end{tabular}

and these in turn are computed from the various cross spectra [see Bendat and Piersol, 1971].

In our coherence analyses (Figures 9-14), each phase could be simply represented, within statistical limits in the energetic long-period ( $>5$ day) bands, by a straight line originating at $0^{\circ}$ or $180^{\circ}$ and having positive slope. This suggests modeling the current response to each forcing function as that due to a uniform time lag (i.e., a displaced delta function impulse response). Assuming linear responses, the shelf current variation (at these periods) could then be represented simply as

$$
v^{\prime}(t)=A \sigma_{U}^{\prime}(t-a)+B \sigma_{V}^{\prime}(t-b)+C \xi^{\prime}(t-c)+E(t)
$$

where $a, b, c$ are the time lags and $A, B, C$ the proportionality coefficient for $\sigma_{U}^{\prime}, \sigma_{V}^{\prime}$, and $\xi^{\prime}$ respectively, where the prime indicates variation and $E$ is the "noise" (i.e., the unpredicted portion of $v^{\prime}$ ). This representation suggests the use of multiple correlation analysis to determine the lags $a, b, c$ and the coefficients $A, B, C$. In practice, knowing from our partial coherence analysis that wind influences (especially longshore wind) dominate at $F$ while Gulf Stream influence dominates at $E$, we have limited our analysis to determining $a, b, A, B$ at site $\mathrm{F}$, and $b, c, B, C$ at site E. Figure 15 shows the multiplecorrelation coefficient, $r$, resulting from multiple regressions of $v^{\prime}$ on the appropriate two inputs, for different lags of these inputs. Prior to the correlation computations, all data series were prewhitened by fitting and removing a second-order polynomial, and low-pass filtered with a Lanczos-squared filter whose transmission is 6 dbar down at 3.3 days. With one exception, $r$ is seen to have a maximum value in each case at lags of 17-24 hours. The exception is the $\sigma_{U}{ }^{\prime}$ lag, $a$, for FBOT, which is not well defined; as shown in Figure 15 (left), there is a ridge in the $r$ topography at $b=17$ hours along which $r$ varies from 0.74 at $a=0$, to 0.75 at $a=48$ hours, an insignificant variation. We have (rather arbitrarily) chosen $a=5$ hours for the "optimum lag" because this is the lag suggested by the slope of the phase lines in Figure $9 a$, and because of a maximum in $r$ at $a=5$ hours appearing in Figure $15 a$ for $b>70$ hours. Table 4 gives the values of $r, r^{2}$, the lags, and the coefficients at the multiple-correlation maximum for each of the $v^{\prime}$ records (ETOP, EBOT, FBOT). Since $r^{2}=0.55$ in each case, it appears that $55 \%$ of the variance in $v$ (at periods from 3 days to 3 months) can be predicted from a simple model of the form (3) with only two input parameters in each case. Using the lags and coefficients in Table 4 "predictions" can be formed for $v^{\prime}$ at each of the three locations, using (4). Figure 16 compares such a prediction for ETOP with the prewhitened and low-pass filtered version of this record on which the prediction was based. Except for a 2-week period beginning February 25 , the larger fluctuations appear well predicted in phase and somewhat less well predicted in amplitude.

\section{Summary}

We have investigated the relationship of variation in longshore currents at the middle and outer shelf off Savannah,

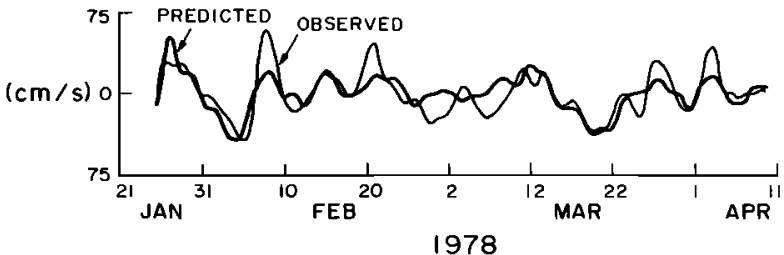

Fig. 16. Predicted (see text) and observed longshore current at ETOP.

Georgia, to variations in local wind and Gulf Stream forcing. Gulf Stream meanderings were tracked by an IES with a pressure gage. Watts and Wimbush's [1981] linear model was used to compute the Gulf Stream main thermocline depth as an indicator of Gulf Stream lateral displacement. A multipleinput linear model was used to diagnose the forcing mechanisms in each frequency band according to the linear regression method of Groves and Hannan [1968].

The following are the principal conclusions from the winter observations off Georgia.

1. The thermocline depth beneath the mean Gulf Stream cyclonic front, as monitored by an IES with a pressure gage, is a good indicator of Gulf Stream lateral displacement. From knowledge of Gulf Stream displacement measured in this way and of local wind stress, one can predict the subtidal variance in longshore current at the shelf break.

2. At the middle shelf, direct effects from the Gulf Stream are negligible and knowledge of local wind stress alone enables one to predict most of the subtidal variance in longshore current (at periods up to 25 days). Longshore wind is responsible for most of the variance at periods longer than 5 days, while the cross-shore wind influence dominates at shorter periods.

3. Low-frequency current variability at the shelf break is a result of both Gulf Stream and wind forcings. The water column is divided by the Gulf Stream front; for water under the front, Gulf Stream and wind influences are comparable, but for water above the front the Gulf Stream influence dominates. In the upper layer, Gulf Stream wavelike meanders at 12-day period and associated frontal eddies appear to be the primary forcing from the Gulf Stream. Secondary coherence peaks occur at 2.5 and 1.4 days. Longshore wind influence is significant at the 6.3- and 2-day periods of its energetic spectral peaks. Cross-shore wind also has some effect at very low frequencies. Longshore current can be well predicted from wind and Gull Stream at periods longer than 5 days and at around 2 days. In the 2.8 - to 5 -day band the prediction is poor, due probably to frontal eddies.

These results confirm the expectations expressed in previous studies [e.g., Lee and Brooks, 1979; Lee et al., 1981; Lee and Atkinson, 1983] with regard to the relative influences of Gulf Stream and wind on mid- and outer-shelf currents off Georgia.

Acknowledgments. Funding for this project was provided by Department of Energy under contract EY-76-S-05-5163 and the Bureau of Land Management (MMS) under prime contract AAT851-CT1-25 to Science Application Inc. of Raleigh, North Carolina, subcontract 11-820294-11. We thank Karen Lorenson for her help in obtaining and converting the IES measurements. We also thank Larry Atkinson of Skidaway Institute of Oceanography and Bradford Butman of the U.S. Geological Survey for providing some of the hydrographic data used in the calibration and analysis of the IES measurements.

\section{REFERENCES}

Allen, J. S., R. C. Beardsley, J. O. Blanton, W. C. Boicourt, B Butman, L. K. Coachman, A. Huyer, T. H. Kinder, T. C. Royer, J. D. Schumacher, R. L. Smith, W. Sturges, and C. D. Winant, Physi- 
cal oceanography of continental shelves, Rev. Geophys. Space Phys., 21, 1149-1181, 1983.

Bane, J. M., Jr., D. A. Brooks, and K. R. Lorenson, Synoptic observation of the three-dimensional structure and propagation of Gulf Stream meanders along the Carolina continental margin, J. Geophys. Res., 86, 6411-6425, 1981.

Bendat, J. S., and A. G. Pierson, Random Data: Analysis and Measurement Procedures, 407 pp., Wiley Interscience, New York, 1971.

Bitterman, D. S., Jr., and D. R. Watts, The inverted echo sounder, IEEE Oceans' '79, 302-306, 1979.

Brooks, D. A., and J. M. Bane, Jr., Gulf Stream deflection by a bottom feature off Charleston, South Carolina, Science, 201, 12251226, 1978.

Brooks, D. A., and J. M. Bane, Jr., Gulf Stream fluctuations and meanders over the Onslow Bay upper continental slope, J. Phys. Oceanogr., 11, 247-256, 1981.

Brooks, D. A., and J. M. Bane, Jr., Gulf Stream meanders off North Carolina during winter and summer 1979, J. Geophys. Res., 88, 4633-4650, 1983.

Chew, F., Shingles, spin-off eddies and an hypothesis, Deep Sea Res., 28A, 379-391, 1981.

Freeland, H. J., P. B. Rhines, and T. Rossby, Statistical observations or the trajectories of neutrally buoyant floats in the North Atlantic, J. Mar. Res., 33, 383-404, 1975.

Groves, G. W., and E. J. Hannan, Time series regression of sea level on weather, Rev. Geophys., 6, 129-147, 1968.

Lee, T. N., and L. P. Atkinson, Low-frequency current and temperature variability from Gulf Stream frontal eddies and atmospheric forcing along the Southeast U.S. outer continental shelf, J. Geophys. Res., 88, 4541-4567, 1983.

Lee, T. N., and D. A. Brooks, Initial observations of current, temperature and coastal sea level response to atmospheric and Gulf Stream forcing on the Georgia shelf, Geophys. Res. Lett., 6, 321324, 1979.

Lee, T. N., and D. A. Mayer, Low-frequency current variability and spin-off eddies on the shelf off Southeast Florida, J. Mar. Res., 35, 193-219, 1977.

Lee, T. N., and E. Waddell, On Gulf Stream variability and meanders over the Blake Plateau at $30^{\circ} \mathrm{N}, J$. Geophys. Res., 88, 4617-4632, 1983.

Lee, T. N., L. P. Atkinson, and R. Legeckis, Observations of a Gulf Stream frontal eddy on the Georgia continental shelf, April 1977, Deep Sea Res., 28, 347-378, 1981.

Lee. T. N., E. Daddio, and G. C. Han, Steady-state diagnostic model of summer mean circulation on the Georgia shelf, J. Phys. Oceanogr., 12, 820-838, 1982.

Lee, T. N., W. J. Ho, V. Kourafalou, and J. D. Wang, Circulation on the continental shelf of the southeast United States, 1, Subtidal response to wind and Gulf Stream forcing during winter, J. Phys. Oceanogr., 14, 1001-1012, 1984.

Legeckis, R. V., Satellite observations of the influence of bottom topography on the seaward deflection of the Gulf Stream off Charleston, South Carolina, J. Phys. Oceanogr., 9, 483-497, 1979.

$\mathrm{Li}, \mathrm{L}$., and M. Wimbush, Bottom temperatures related to Gulf Stream displacement off the southeast U.S. shelf, J. Atmos. Oceanic Technol., in press, 1985.

McClain, C. R., L. J. Pietrafesa, and J. A. Yoder, Observations of Gulf Stream-induced and wind-driven upwelling in the Georgia Bight using color and infrared imagery, J. Geophys. Res., 89, 3705-3723, 1984 .

Munk, W. H., and D. E. Cartwright, Tidal spectroscopy and prediction, Philos. Trans. R. Soc. London, 259, 533-581, 1966.

Pietrafesa, L. J., Survey of a Gulf Stream frontal filament, Geophys. Res. Lett., 10, 203-206, 1983.

Pietrafesa, L. J., and G. S. Janowitz, On the dynamics of the Gulf Stream front in the Carolina capes, Proceedings of the Second International Symposium on Stratified Flows, Tapin Publishing, Trondheim, Norway, 1980.

Pietrafesa, L. J., J. O. Blanton, and L. P. Atkinson, Evidence for deflection of the Gulf Stream at the Charleston Rise, Gulf Stream, 4(9), 3-7, 1978.

Rossby, T., On monitoring depth variations of the main thermocline acoustically, J. Geophys. Res., 74, 5542-5546, 1969.

Saunders, P. M., Wind stress on the ocean over the eastern continental shelf of North America, J. Phys. Oceanogr., 7, 555-566, 1977.

Tebeau, P. A., and T. N. Lee, Wind induced circulation on the Georgia shelf, (winter 1976/77), RSMAS Tech Rep. 79003, Univ. of Miami, Miami, Fla., 1979.

Watts, D. R., and W. E. Johns, Gulf Stream meanders: Observations on propagation and growth, J. Geophys. Res., 87, 9467-9476, 1982.

Watts, D. R., and H. T. Rossby, Measuring dynamic heights with inverted echo sounders: Results from MODE, J. Phys. Oceanogr., 7, 345-358, 1977.

Watts, D. R., and M. Wimbush, Sea surface height and thermocline depth variations measured from the sea floor, Proceedings of the International Symposium on Acoustic Remote Sensing of the Atmosphere and Oceans, Univ. of Calgary, Calgary, Alberta, June 22-25, 1981.

Weber, A. H., and J. O. Blanton, Monthly mean wind fields for the South Atlantic Bight, J. Phys. Oceanogr., 10, 1256-1263, 1980.

Webster, F., A description of Gulf Stream meanders off Onslow Bay, Deep Sea Res., 8, 130-143, 1961.

Weisberg, R. H., and L. J. Pietrafesa, Kinematics and correlation of the surface wind field in the South Atlantic Bight, J. Geophys. Res., $88,4593-4610,1983$.

Wimbush, M., An inexpensive sea floor precision pressure recorder, Deep Sea Res., 24, 493-497, 1977.

A. J. Brincko, D. R. Watts, and M. Wimbush, Graduate School of Oceanography, University of Rhode Island, Kingston, RI 02881.

T. N. Lee, School of Marine and Atmospheric Science, Division of Meteorology and Physical Oceanography, University of Miami, Miami, FL 33149.

L. Li, Third Institute of Oceanography, National Bureau of Oceanography, Xiamen, People's Republic of China.

(Received May 14, 1984; accepted July 30,1984 .) 